\title{
Recrystallization-based formation of uniform fine-grained austenite structure before polymorphic transition in high- strength steels for Arctic applications
}

\author{
Pavel Layus ${ }^{1 *} \mathbb{0}$, Paul Kah¹, Alexander Zisman², Markku Pirinen ${ }^{1}$ and Sergey Golosienko²
}

\begin{abstract}
Background: Growing demand for materials suitable for Arctic marine constructions necessitates the development of lowcost steels with excellent low-temperature properties. One way of addressing this issue is to obtain a finegrained structure by careful control of the recrystallization process.

Methods: The research methods used in this paper includes conducting experiments and making observations. The study investigates mechanisms of grain structure formation in low-carbon cold-resistant F620 steels additionally alloyed with $\mathrm{Nb}$ or $\mathrm{V}$ during hot plastic deformation.

Results: The obtained results evidence that static recrystallization is the most effective means to refine the austenite structure under conditions of industrial rolling. On this basis, a temperature-strain scheme of fractional hot rolling is proposed that provides the most refined uniform structures of bainite and/or martensite after quenching. Additionally, the results show that substitution of the alloying element $\mathrm{V}$ by Nb makes the structure of the hot-rolled austenite more finely dispersed.

Conclusions: New cold-resistant F620 steels for Arctic applications alloyed with Nb of 50-mm thickness were produced utilizing the research results. These grades of steels have reduced alloying content and exhibit improved properties, in particular, cold resistance down to $-60{ }^{\circ} \mathrm{C}$ and high fracture toughness at $-50{ }^{\circ} \mathrm{C}$.
\end{abstract}

Keywords: Arctic conditions, Recrystallization, Static recrystallization, Dynamic recrystallization, Cold-resistance steel, High-strength steel

\section{Background}

Simultaneously high levels of strength and cold resistance are commonly obtained in shipbuilding steels by alloying with elements such as $\mathrm{Ni}, \mathrm{Mo}, \mathrm{Cr}, \mathrm{Cu}, \mathrm{Nb}, \mathrm{Ti}$, and $\mathrm{V}$ which add considerably to the cost of the steel (Khlusova et al. 2007). Consequently, the growing demand for Arctic steels is promoting research in and development of suitable low-cost steels and their respective technologies. At the same time, however, quality requirements are becoming still more severe. For example, the Russian Maritime Register of Shipping has imposed more stringent

\footnotetext{
* Correspondence: pavel.layus@lut.fi

'Welding Technology Laboratory, Lappeenranta University of Technology, PL 20, 53851 Lappeenranta, Finland

Full list of author information is available at the end of the article
}

requirements on ductility, cold resistance, and fracture toughness of "Arc-steels" while maintaining previous high-strength requirements (Russian Maritime Register of Shipping. Rules for the Classification \& Construction and Equipment of Mobile Offshore Platforms 2012). Such a complex combination of qualities is feasible in thick rolled products only when fine-grained structures are present (Calcagnotto et al. 2009; Leinonen 2004; Salvatori 2006). Refining of austenite grains is possible by utilizing recrystallization (dynamic-DRx, metadynamic-MDRx, and static-SRx) (Gorelik et al. 2005) and fragmentation (Kodzhaspirov et al. 2006) processes under specific thermomechanical conditions (Fernández et al. 2003). In addition, the structure formation over the whole cycle of hot rolling is sensitive to small additions $(\sim 0.01 \%)$ of $\mathrm{Nb}, \mathrm{Ti}$, or $\mathrm{V}$, 
which hinder boundary migration and, hence, grain growth (Sha \& Sun 2009; Sha et al. 2011; Jung et al. 2011). The present paper investigates the effects of temperature and strain degree on DRx and SRx kinetics in austenite of cold-resistant high-strength steel F620 presented with two micro-alloying options-with $\mathrm{V}$ or $\mathrm{Nb}$. The chemical composition of steel F620 according to various certification societies and the one used in this study is provided in Table 1.

\section{Methods}

\section{Dynamic recrystallization experiments}

The threshold strain ( $\varepsilon \mathrm{p}$ ) related to DRx start was determined with stress-strain diagrams $(\sigma-\varepsilon)$ based on characteristic stress maxima. Stress-strain diagrams for the steels in this study are shown in Fig. 1. At the highest temperature, $1150{ }^{\circ} \mathrm{C}$, both steels display maximum stress values $(\sigma \approx 90 \mathrm{MPa})$ at lower values of strain $(\varepsilon \mathrm{p} \approx 0.3 \%)$, as shown in Fig. 1 a by the red dotted line. Here, $\mathrm{Nb}$ augments $\varepsilon \mathrm{p}$ by about $0.005 \%$, slightly hindering DRx though not stopping the process. When the temperature decreases down to $1050{ }^{\circ} \mathrm{C}$, the $\mathrm{Nb}$ effect becomes most pronounced, since, unlike steel F620 alloyed with V $(\varepsilon p \approx$ $0.45 \%)$, there are no signs of austenite DRx in F620 alloyed with $\mathrm{Nb}$ up to true strain of $0.9 \%$. At the lowest temperature, $950{ }^{\circ} \mathrm{C}$, the $\mathrm{DRx}$ process ceases in both steels. The diagrams in Fig. 1 also show that the general hardening effect due to $\mathrm{Nb}$ becomes stronger when the deformation temperature is reduced.

In order to form a sufficiently uniform refined structure, the small austenite grains inherent in DRx should cover a high enough volume fraction. However, even at $T>1050{ }^{\circ} \mathrm{C}$, this is possible only if single strains exceed $0.9 \%$, which is unrealistic in industrial rolling. Therefore, austenite formation during DRx remains incomplete, and hence, an unwanted non-uniform structure forms (coexistence of fine and coarse grains) that reduces the ductility of the steel. As evident in Fig. 1, this characteristic previously known with the traditional steel F620 alloyed with V (Zisman et al. 2012) remains valid for its modification alloyed with $\mathrm{Nb}$. Therefore, the growth of threshold $\varepsilon p$ due to $\mathrm{Nb}$ proves to have an additional positive effect because it more reliably excludes incomplete DRx and related grain size variation. The grain size was measured according to ISO 643: 2003 standard.

\section{Static recrystallization experiments}

To investigate SRx of austenite, the stress relaxation method (Zisman et al. 2012; Perttula \& Karjalainen 1998) was implemented on a Gleeble 3800 simulator. The selected degrees of 0.25 and 0.10 of single strains correspond, respectively, to the maximum thickness reduction during rough rolling and the average reduction in finish rolling of the investigated steels. Distinct changes in the softening rate $\mathrm{d} \sigma / \mathrm{d} t$ allow determination of the incubation period of SRx and the time span of its primary stage (Zisman et al. 2012; Perttula \& Karjalainen 1998). Stress relaxation curves for austenite of $F 620$ alloyed with $\mathrm{V}$ and $\mathrm{Nb}$, correspondingly, are indicated in Figs. 2 and 3 by labels "V" and "Nb." When the incubation period and duration of primary SRx could be derived from the diagrams, these time parameters are indicated by light and dark circles, respectively; stars indicate the time when the SRx degree reached $80 \%$. Following, the SRx degree is evaluated as (Zisman et al. 2012)

$$
P(t)=(\sigma \max -\sigma \mathrm{t}) /(\sigma \max -\sigma \min ),
$$

where $\sigma$ max and $\sigma$ min are the maximum and minimum stress magnitudes during the SRx, respectively, and ot is the stress magnitude at a current time $t$.

Stress relaxation diagrams after $\varepsilon=0.25 \%$ (Fig. 2) show that during technological pauses (several seconds or tens of seconds) austenite SRx in both steels becomes complete only at $T \geq 1000{ }^{\circ} \mathrm{C}$. At $T=950{ }^{\circ} \mathrm{C}$, this process remains uncompleted in the steel micro-alloyed by $\mathrm{Nb}$ and at lower temperatures in both steels. After $\varepsilon=0.10 \%$ (Fig. 3), SRx becomes much slower and becomes complete in the abovementioned pauses only at relatively high temperatures of $T \geq 1100{ }^{\circ} \mathrm{C}$. Earlier termination of SRx due to $\mathrm{Nb}$ addition accelerates the growth of the dislocation density and hence extends the range of austenite fragmentation (subgrain structure evolution) to higher temperatures (Kodzhaspirov et al. 2006; Rybin 1986). Nevertheless, previous SRx still remains significant, since the fragmentation rate increases with the grains' refinement (Rybin 1986).

\section{Results and discussion}

Samples of both F620 steels alloyed with V or Nb were subjected to two treatments on the Gleeble 3800 simulator. The treatments included five sequential strains, separated by pauses, in a temperature range of 950 to $1150{ }^{\circ} \mathrm{C}$. In the first treatment, the pauses were not regulated; in the second treatment, the pause durations, increasing with the temperature reduction, were selected to provide complete primary SRx in each case. The true strains, strain rate, and following cooling rate were $0.15 \%, 1 \mathrm{~s}^{-1}$ and $30{ }^{\circ} \mathrm{C} / \mathrm{s}$, respectively.

As can be seen from Figs. $4 \mathrm{a}-\mathrm{c}$ and $5 \mathrm{a}-\mathrm{c}$, the most dispersed structure and therefore the highest hardness (Figs. $4 \mathrm{~d}$ and $5 \mathrm{~d}$ ) are provided by the treatment with regulated pauses selected based on the austenite SRx kinetics of F620 steels alloyed with $\mathrm{V}$ or $\mathrm{Nb}$.

Rolled products of up to $50-\mathrm{mm}$ thickness were fabricated from a new lower-alloyed cold-resistant steel, F620 (alloyed with $\mathrm{Nb}$ ), with a rolling scheme based on the above findings. The average tensile strength was $760 \mathrm{MPa}$ (700-890 MPa required by specification) 
Table 1 Chemical composition of F620, wt. \%

\begin{tabular}{|c|c|c|c|c|c|c|c|c|c|c|c|c|c|c|c|c|}
\hline Steel grade & $C$ & $\mathrm{Mn}$ & $\mathrm{Si}$ & $\mathrm{P}$ & $S$ & $\mathrm{Cu}$ & $\mathrm{Ni}$ & Mo & $\mathrm{Cr}$ & $\mathrm{Al}$ & $\mathrm{Nb}$ & V & $\mathrm{Ti}$ & $\mathrm{V}+\mathrm{Nb}+\mathrm{Ti}$ & $\mathrm{N}$ & B \\
\hline F620 $\left(B V^{a}\right)$ & 0.18 & 1.6 & 0.55 & 0.025 & 0.02 & 1.5 & 2 & 1 & 2 & 0.015 & 0.06 & 0.1 & 0.2 & - & 0.02 & 0.06 \\
\hline F620W $\left(\mathrm{DNV} \mathrm{V}^{\mathrm{b}}\right)$ & 0.18 & 1.6 & $0.1-0.55$ & 0.025 & 0.025 & 0.35 & 0.8 & 0.08 & 0.2 & 0.02 & $0.02-0.05$ & $0.05-0.1$ & $0.007-0.02$ & 0.12 & 0.02 & - \\
\hline F620W (Lloyd ${ }^{C}$ ) & 0.18 & 1.6 & 0.55 & 0.025 & 0.025 & - & - & - & - & $0-0.015$ & $0.02-0.05$ & $0.03-0.1$ & 0.02 & 0.12 & 0.02 & - \\
\hline F620W $\left(\mathrm{RMRS}^{\mathrm{d}}\right)$ & 0.18 & 1.6 & 0.55 & 0.025 & 0.025 & - & - & - & - & - & - & - & - & - & 0.02 & - \\
\hline $\begin{array}{l}\text { F620W } \\
\text { with V (TU⿱e })\end{array}$ & $0.08-0.10$ & $0.3-0.6$ & $0.17-0.37$ & - & - & \multicolumn{2}{|c|}{$\begin{array}{l}\mathrm{Cu} \\
+\mathrm{Ni}: 2.2-2.9\end{array}$} & \multicolumn{2}{|c|}{$\begin{array}{l}\text { Mo } \\
+ \text { Cr:0.55-1.05 }\end{array}$} & - & - & $0.01-0.03$ & - & - & - & - \\
\hline $\begin{array}{l}\text { F620W with } \\
\mathrm{Nb}\left(\mathrm{TU}^{\mathrm{e}}\right)\end{array}$ & $0.08-0.10$ & $0.3-0.6$ & $0.17-0.37$ & - & - & \multicolumn{2}{|c|}{$\mathrm{Cu}+\mathrm{Ni}: 2.2-2.9$} & \multicolumn{2}{|c|}{$\mathrm{Mo}+\mathrm{Cr}: 0.55-1.05$} & - & $0.01-0.03$ & - & - & - & - & - \\
\hline
\end{tabular}

If the range is not specified, the maximum allowable value is given

aBureau Veritas

${ }^{\mathrm{b}}$ Det Norske Veritas

${ }^{\mathrm{d}}$ Russian Maritime Register of Shipping

${ }^{\mathrm{e}} \mathrm{TU}$ 5.961-11571-95 (chemical composition used in this study) 

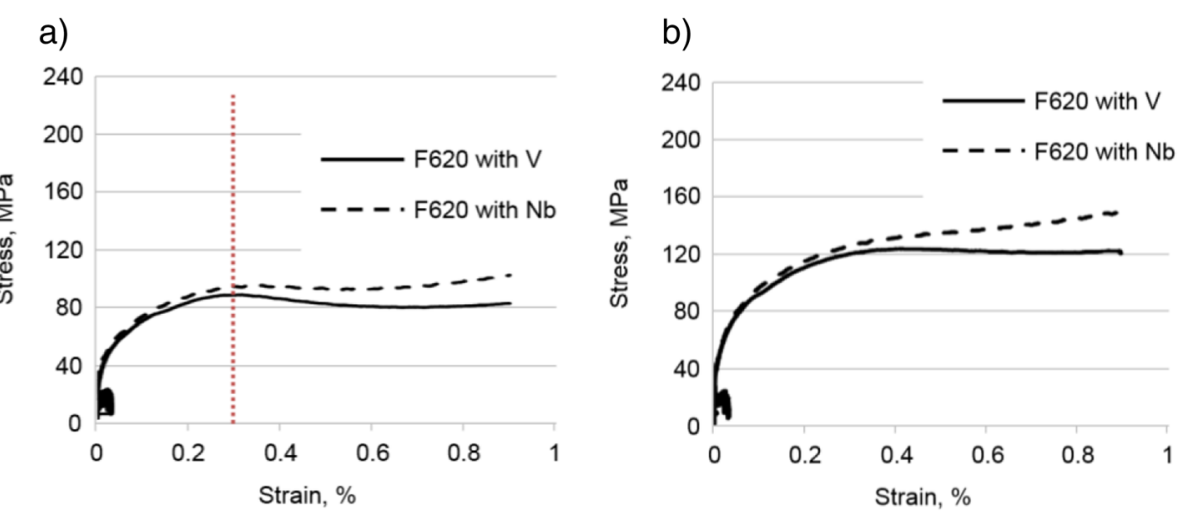

c)

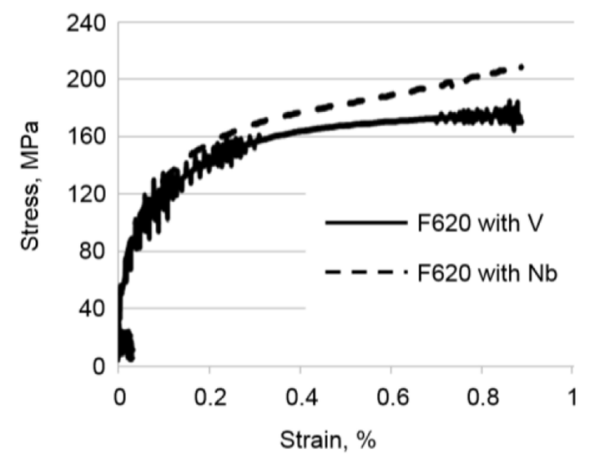

Fig. 1 Loading stress-strain diagrams of F 620 with $\mathrm{V}$ and $\mathrm{Nb}$ steels at a $T=1150{ }^{\circ} \mathrm{C}, \mathbf{b} T=1050{ }^{\circ} \mathrm{C}$, and $\mathbf{c} T=950{ }^{\circ} \mathrm{C}$

a)

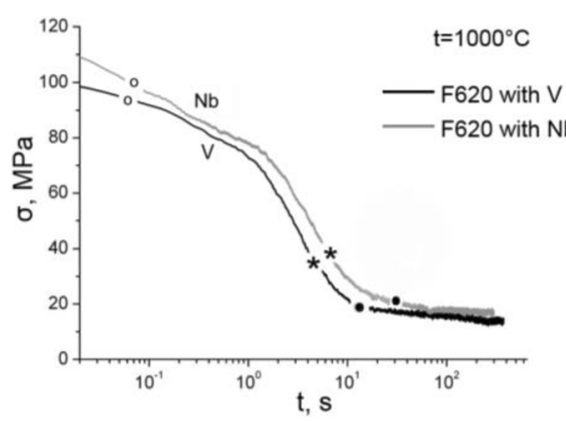

c)

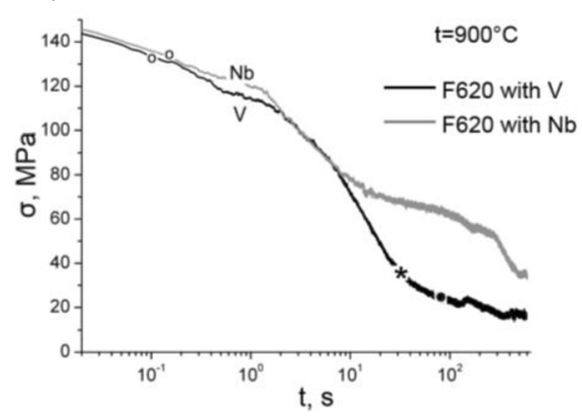

b)

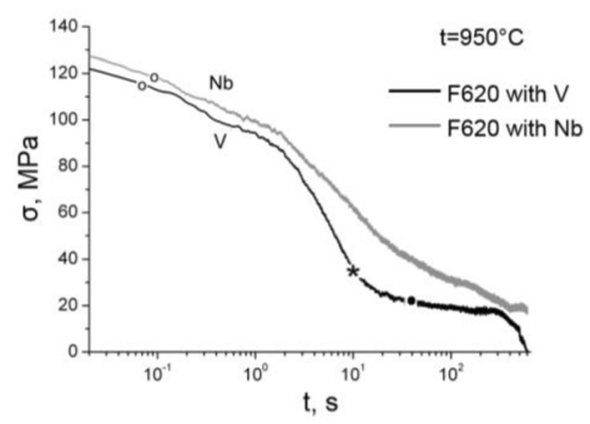

d)

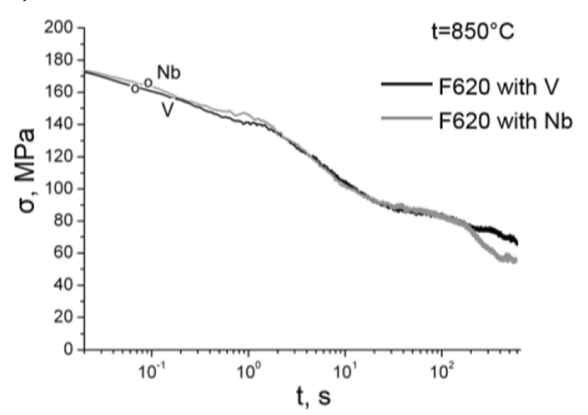

Fig. 2 Stress relaxation of F620 steel alloyed with $\mathrm{V}$ and $\mathrm{Nb}$ after true strain of $0.25 \%$ at temperatures of $\mathbf{a} 1000{ }^{\circ} \mathrm{C}, \mathbf{b} 950{ }^{\circ} \mathrm{C}, \mathbf{c} 900{ }^{\circ} \mathrm{C}$, and $\mathbf{d} 850{ }^{\circ} \mathrm{C}$ 
a)

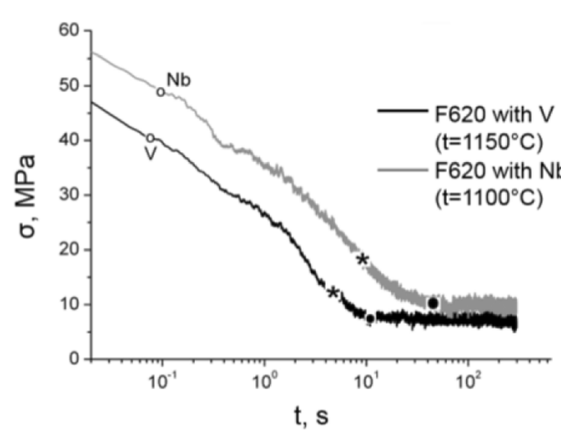

c)

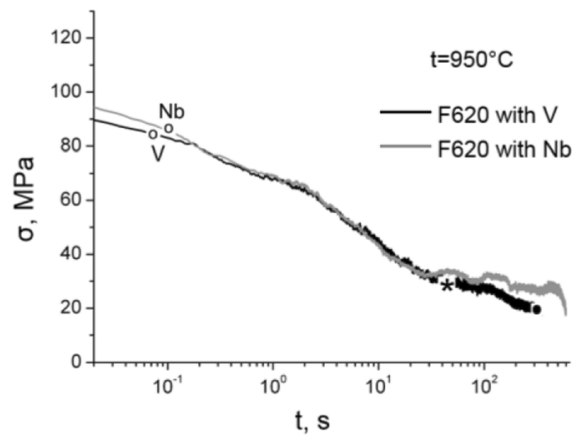

b)

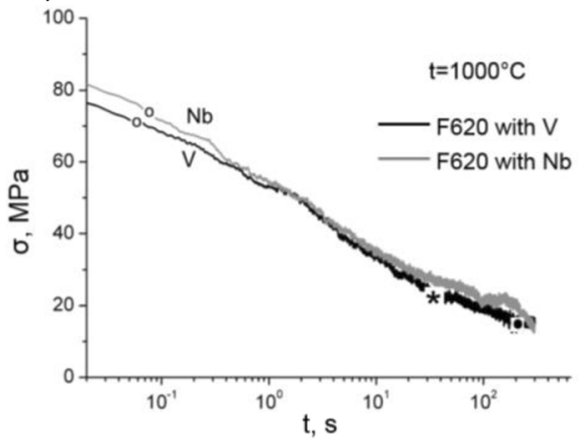

d)

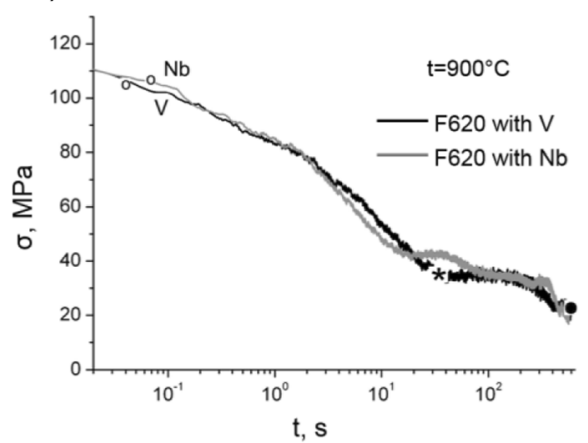

Fig. 3 Stress relaxation of $F 620$ steel alloyed with $\mathrm{V}$ and $\mathrm{Nb}$ after true strain of $0.10 \%$ at temperatures of a 1100 and $1150{ }^{\circ} \mathrm{C}$, b $1000{ }^{\circ} \mathrm{C}$, c $950^{\circ} \mathrm{C}$, and $\mathbf{d} 900^{\circ} \mathrm{C}$

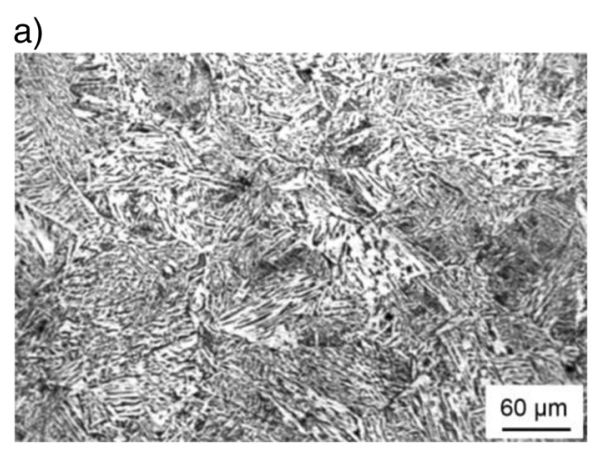

c)

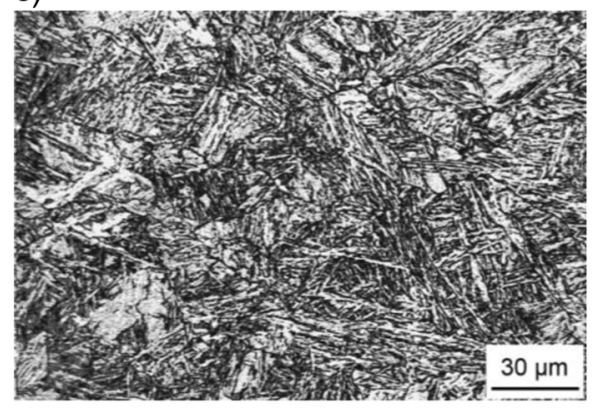

b)

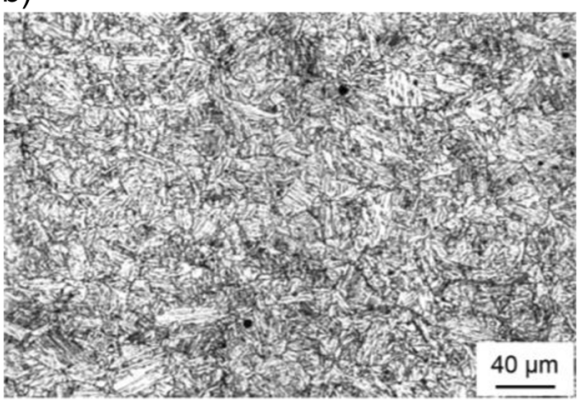

d)

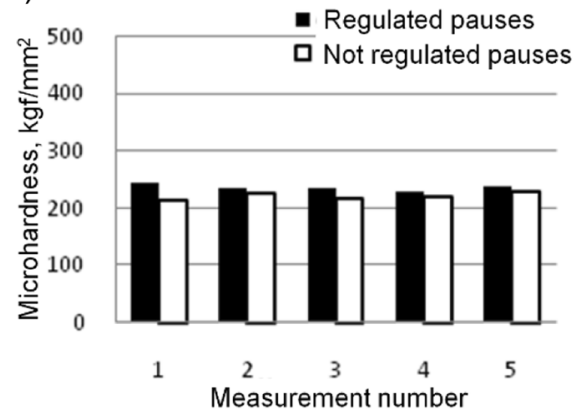

Fig. 4 Microstructure F620 steel alloyed with V: a transformed from austenite exposed for $60 \mathrm{~s}$ at $T=1200{ }^{\circ} \mathrm{C}_{,} D_{\gamma}=120 \mu \mathrm{m}$; $\mathbf{b}$ austenite deformed with pauses regulated, $D_{\gamma}=17 \mu \mathrm{m} ; \mathbf{c}$ not regulated, $D_{\gamma}=90 \mu \mathrm{m}$; and $\mathbf{d}$ microhardness 


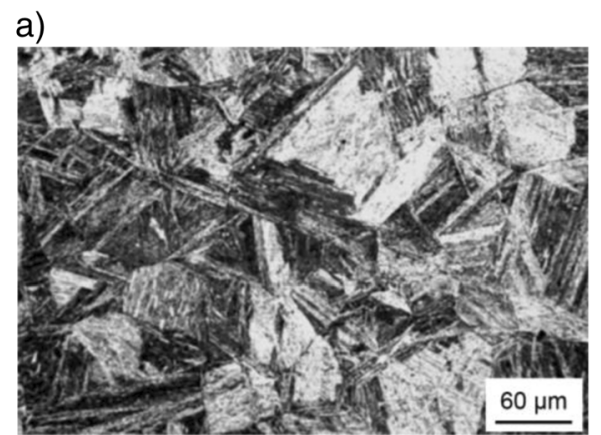

C)

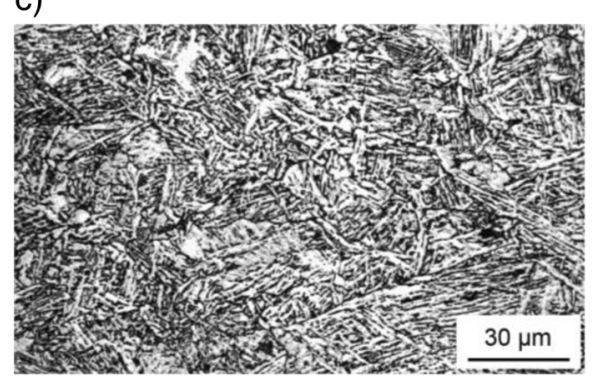

b)

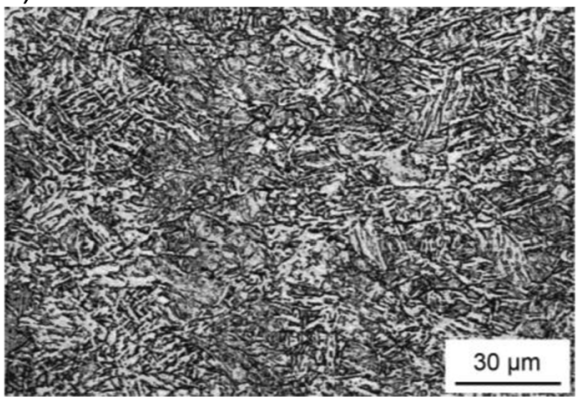

d)

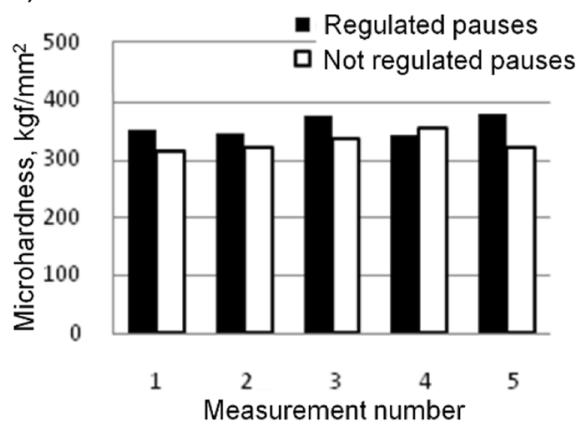

Fig. 5 Microstructure of F620 steel alloyed with Nb: a transformed from austenite exposed for $60 \mathrm{~s}$ at $T=1200{ }^{\circ} \mathrm{C}, D_{\gamma}=100 \mu \mathrm{m} ; \mathbf{b}$ austenite deformed with pauses regulated, $D_{Y}=15 \mu \mathrm{m}$; $\mathbf{c}$ not regulated, $D_{\gamma}=50 \mu \mathrm{m}$; and $\mathbf{d}$ microhardness

and the yield stress $700 \mathrm{MPa}(\geq 620 \mathrm{MPa}$ required by specification). The alloying level, as reflected by the toughness parameter Pcm, was $0.22 \%$. Apart from the required strength, the rolled products of Arc-steel showed high ductility ( $\left.\delta_{5} \geq 20 \%\right)$, good toughness, and cold resistance down to $-60{ }^{\circ} \mathrm{C}$ (Figs. 5 and 6). All tests were performed on whole thickness samples. The requirements for steels are provided according to Russian Maritime Register of Shipping (RMRS) rules. The quality characteristics of the lower-alloyed coldresistant steel are the result of the finely dispersed structures of bainite-martensite mixture obtained by $\gamma-\alpha$ transition from the fine-grained austenite. The testing results of F620 steels alloyed with $\mathrm{V}$ or $\mathrm{Nb}$ demonstrate the effectiveness of the new procedure.

\section{Conclusions}

The outcomes and conclusions of the conducted research are:

1. During rough rolling $\left(T>1050^{\circ} \mathrm{C}\right.$ for F620 steel alloyed with $\mathrm{V}$ and $T>1100{ }^{\circ} \mathrm{C}$ for $\mathrm{Nb}$-alloyed steel), incomplete DRx can occur, resulting in non-uniformity (grain size) of the austenite structure. To prevent this unwanted effect, it is necessary to regulate successive deformations.

2. A uniform fine-grained austenite structure may be obtained during rough rolling if primary SRx is completed within each pause; to this end, it is necessary to gradually increase the durations of the pause between successive deformations in the range $1150-950{ }^{\circ} \mathrm{C}$ for
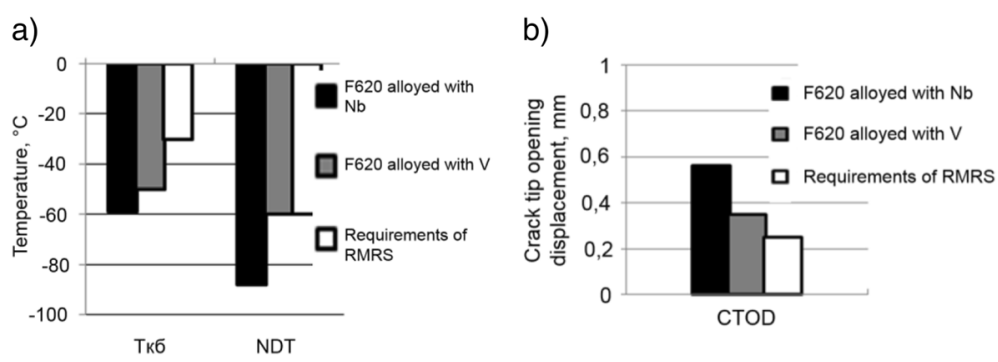

Fig. 6 Properties of F620 steel. a Parameters of cold resistance (characteristic temperatures TK6 and NDT); $\mathbf{b}$ fracture toughness (CTOD at $-40{ }^{\circ} \mathrm{C}$ ) 
F620 V-alloyed steel and $1150-1050{ }^{\circ} \mathrm{C}$ for F620 Nballoyed steel.

3. Substitution of $\mathrm{V}$ by $\mathrm{Nb}$ in $\mathrm{Cr}-\mathrm{Ni}$-Mo steels makes the structure of the hot-rolled austenite more finely dispersed as a result of a number of effects: (a) limitation on grain growth during the metal heating before rolling; (b) prevention of DRx, which may be only partial (incomplete) for technological reasons and can result in structural non-uniformity; (c) prevention of growth of new grains formed by primary SRx; and (d) extension to higher temperatures of the range of austenite fragmentation, forming new interfaces within grains.

4. Rolled products of 50-mm thickness fabricated from a new cold-resistant $\mathrm{Nb}$-alloyed F620 steel with reduced alloying and made following the discussed procedure display improved product characteristics, in particular, cold-resistance down to $-60{ }^{\circ} \mathrm{C}$ and high fracture toughness at $-50{ }^{\circ} \mathrm{C}$. The steel is recommended for Arctic applications.

\section{Competing interests}

The authors declare that they have no competing interests.

\begin{abstract}
Authors' contributions
PL has drafted the paper, prepared data and provided explanations for the experimental results. PK shared expert advice and helped to complete the paper with European perspective on the study. AZ conducted the experiments and shared expert advice on the paper and proposed conclusions of the paper. MP managed the research project and took part in the discussions and conclusion formulating. SG participated in the experiments and supported the paper development. All authors read and approved the final manuscript.
\end{abstract}

\section{Acknowledgements}

This research was supported by an ENPI project Arctic Materials Technology Development.

\section{Author details}

'Welding Technology Laboratory, Lappeenranta University of Technology, PL 20, 53851 Lappeenranta, Finland. ${ }^{2}$ Central Research Institute of Structural Materials Prometey, Saint-Petersburg, Russia.

Received: 17 December 2015 Accepted: 7 March 2016

Published online: 15 March 2016

\section{References}

Khlusova, El, Kruglova, AA, \& Orlov, W (2007). The effect of chemical composition, heat and strain treatment on the size of austenite grains in low-carbon steels (in Russian). Metall heat Treat Met., 12, 3-8.

Russian Maritime Register of Shipping (2012). Rules for the classification, construction and equipment of mobile offshore platforms. 2, 445

Calcagnotto M, Ponge D, Adachi Y, Raabe D (2009) Effect of grain refinement on strength and ductility in dual-phase steels [Internet]. In: Proceedings of the 2nd International Symposium on Steel Science (ISSS 2009). Kyoto: Iron and Steel Institute of Japan (ISIJ); pp. 195-198. Available from: http://edoc.mpg.de/439324.

Leinonen, Jl (2004). Superior properties of ultra-fine-grained steels. Acta Polytechnica, 44(3), 37-40.

Salvatori, I (2006). Ultrafine grained steels by advanced thermomechanical processes and severe plastic deformations. La Metall Ital., 5, 41-47.

Gorelik, SS, Dobatkin, SV, \& Kaputkina, LM (2005). Recrystallization of metals and alloys. Moscow: MISIS

Kodzhaspirov, GE, Rudskoy, Al, \& Rybin, W (2006). Physical bases and sustainable manufacturing techniques for plastic deformation (in Russian). Saint Petersburg Russia: Nauka.
Fernández, Al, Uranga, P, \& López, B (2003). Dynamic recrystallization behavior covering a wide austenite grain size range in $\mathrm{Nb}$ and $\mathrm{Nb}$-Ti microalloyed steels. Materials Science and Engineering A, 361, 367-376.

Sha, Q, \& Sun, Z (2009). Grain growth behavior of coarse-grained austenite in a $\mathrm{Nb}-\mathrm{V}-\mathrm{Ti}$ microalloyed steel. Materials Science and Engineering A, 523, 77-84.

Sha, Q, Huang, G, Guan, J, Ma, X, \& Li, D (2011). A new route for identification of precipitates on austenite grain boundary in an $\mathrm{Nb}-\mathrm{V}$-Ti microalloyed steel. Journal of Iron and Steel Research, International [Internet], 18(8), 53-57. Available from: http://dx.doi.org/10.1016/S1006-706X(11)60104-0.

Jung, J, Park, J, Kim, J, \& Lee, Y (2011). Carbide precipitation kinetics in austenite of a $\mathrm{Nb}-\mathrm{Ti}-\mathrm{V}$ microalloyed steel. Materials Science and Engineering: A [Internet], 528(16-17), 5529-5535. Available from: http//dx.doi.org/10.1016/j.msea.2011.03.086.

Zisman, AA, Soshina, TV, \& Khlusova, El (2012). Studies of austenite recrystallization in hot rolled steel 09 HN2MD by stress relaxation (in Russian). Progress in Materials Science, 2, 16-24.

Perttula, JS, \& Karjalainen, LP (1998). Recrystallisation rates in austenite measured by double compression and stress relaxation methods. Materials Science and Technology, 14(7), 626-630.

Rybin, W (1986). Large plastic deformation and fracture. Moscow: Metallurgia.

\section{Submit your manuscript to a SpringerOpen ${ }^{\circ}$ journal and benefit from:}

- Convenient online submission

- Rigorous peer review

- Immediate publication on acceptance

- Open access: articles freely available online

- High visibility within the field

- Retaining the copyright to your article

Submit your next manuscript at springeropen.com 